\title{
67 University of Glasgow
}

Kontonikas, A., Nolan, C., Zekaite, Z. and Lamla, M. (2019) Treasuries variance decomposition and the impact of monetary policy. International Journal of Finance and Economics, 24(48-50), pp. 15061519. (doi: 10.1002/ijfe.1744)

The material cannot be used for any other purpose without further permission of the publisher and is for private use only.

There may be differences between this version and the published version. You are advised to consult the publisher's version if you wish to cite from it.

This is the peer reviewed version of the following article:

Kontonikas, A., Nolan, C., Zekaite, Z. and Lamla, M. (2019) Treasuries variance decomposition and the impact of monetary policy. International Journal of Finance and Economics, 24(48-50), pp. 1506-1519, which has been published in final form at: $\underline{10.1002 / i j f e .1744}$

This article may be used for non-commercial purposes in accordance with Wiley Terms and Conditions for Self-Archiving.

https://eprints.gla.ac.uk/190615/

Deposited on: 19 July 2019

Enlighten - Research publications by members of the University of Glasgow $\underline{\text { http://eprints.gla.ac.uk }}$ 


\title{
Treasuries Variance Decomposition and the Impact of Monetary
}

\author{
Policy
}

Alexandros Kontonikas ${ }^{1 \S}$, Charles Nolan ${ }^{\xi}$, Zivile Zekaite and Michael Lamla* $^{\star}$

\begin{abstract}
This paper investigates the effect of monetary policy shifts on Treasuries over the last three decades. Using Campbell and Ammer's (1993) framework, we decompose unexpected excess returns on 2-, 5- and 10-year Treasuries in three components related to revisions in expectations (news) about future excess returns, inflation and real interest rates. We evaluate the impact of conventional and unconventional monetary policy shocks on returns and their components. Our results indicate that expansionary monetary policy shocks are associated with declining inflation expectations and higher Treasuries' returns.
\end{abstract}

Keywords: Bond Market Variance Decomposition; Monetary Policy; Financial Crisis. JEL classification: G12; G01; E44; E52.

\footnotetext{
${ }^{\S}$ Corresponding author. Prof. Alexandros Kontonikas, Essex Business School, Finance Subject Group, University of Essex, Colchester, CO4 3SQ, UK, a.kontonikas@essex.ac.uk, Tel. +44 (0) 1206874569.

* Prof. MichaeL Lamla, Essex Business School, University of Essex, Colchester, CO4 3SQ, UK, mlamla@essex.ac.uk, Tel. +44 (0) 1206874523.

$\xi$ Prof. Charles Nolan, Adam Smith Business School, Economics Subject Area, University of Glasgow, Glasgow, G12 8QQ, UK, charles.nolan@ glasgow.ac.uk.

${ }^{\ddagger}$ Dr. Zivile Zekaite, Monetary Policy Division, Central Bank of Ireland, North Wall Quay, Dublin, D01 F7X3, Ireland, zivile.zekaite@ centralbank.ie. This work is based on a chapter of my PhD thesis. The views presented in this paper are those of the authors alone and do not represent the official views of the Central Bank of Ireland or the European System of Central Banks.
}

We would like to thank J. Ammer, C. Burnside, J. Campbell, J. Cochrane, A. Duncan, C. Favero, C. Florackis, A. Kostakis, conference participants at the 2015 SIRE Asset Pricing Conference, the 2015 Money Macro and Finance Conference, the 2015 Scottish Area Group BAFA Conference, the 4th UECE Conference on Economic and Financial Adjustments, and the 2016 Financial Management Association European Conference, and seminar participants at the Queen's University Management School, the Lisbon School of Economics and Management, and the Athens University of Economics and Business for useful comments and suggestions. We would also like to thank Tom Doan for helpful advice on the estimation code. 


\section{Introduction}

The greatest part of the three-decade long bull-run in Treasuries took place within an environment of low and stable inflation and sustained economic growth. Starting from the mid1980s, the macroeconomic tranquillity that defined the Great Moderation era was accompanied by — some argue delivered by - an apparently simple and predictable rule underlying the conduct of monetary policy, based upon targeting of the Federal funds rate (FFR). That era of stability and predictability came to an abrupt end with the global financial crisis of 2007-2009. As the zero lower bound on interest rates constrained policymakers in the US and elsewhere, conventional monetary policy was unable to boost economic activity. The Federal Reserve (Fed) adopted non-conventional policy tools, including liquidity facilities and outright purchases of Treasury bonds and other assets from the private sector, to improve financial market conditions and reduce longer-term interest rates. After almost six years of unprecedented expansion in the Fed's balance sheet, the end of quantitative easing (QE) was announced in October 2014.

This study conducts an empirical investigation of the role of monetary policy for Treasuries over the last three decades using the framework of Campbell and Ammer (1993) (hereafter $\mathrm{C} / \mathrm{A}$ ). We use identities linking unexpected excess bond returns to revisions in expectations (news) about future excess returns, inflation and real interest rates. To identify the sources of the bond market's response to monetary policy shocks, we modify Bernanke and Kuttner's (2005) extension of C/A's framework so that it is applicable to bond market returns. ${ }^{2}$ At the first stage of our analysis, we decompose unexpected excess returns on 2-, 5- and 10year Treasury bonds to news about future excess returns, inflation and real interest rates. At the second stage, we evaluate the impact of conventional and unconventional monetary policy

\footnotetext{
${ }^{2}$ News are identified using a VAR time-series econometric model. The decomposition of returns to news terms was pioneered in bond market studies by C/A who built upon Campbell and Shiller's (1988) and Campbell's (1991) earlier work for the stock market.
} 
shifts on Treasury bond returns and their components. We use an FFR-based measure to capture conventional policy shocks, while non-conventional policies are captured using unexpected changes in the monetary base.

We contribute to the existing literature in three ways. First, by using an approach that allows us to explain the bond market reaction to monetary policy shocks over the last three decades on the basis of news about macro-fundamentals and risk. Second, by paying special attention to the role of the financial crisis and the non-conventional policies subsequently adopted by the Fed. Third, by considering shorter maturities, in addition to the often analysed 10-year Treasury bond, in order to examine whether the effects vary across the yield curve.

Previewing our empirical results, the main findings can be summarized as follows. First, across different maturities, variance decomposition results show that news about future inflation is the key factor in explaining the variability of unexpected excess Treasury bond returns during the era of lower inflation that commenced in the mid-1980s. On the other hand, the influence of risk premium news and real interest news is substantially lower. Second, we find that unexpected monetary easing is generally associated with higher excess Treasury bond returns. Third, in the case of quantity-based monetary policy indicators, our results are driven largely by developments at the peak of the financial crisis in autumn 2008 when unprecedented expansion in the Fed's balance sheet was accompanied by a stronger bond market response to money growth. This finding implies an asymmetric bond market response to positive vs. negative money growth shocks, with the former being more important over the recent past. Finally, our results highlight the importance of inflation news in explaining the bond market reaction to monetary policy. We find that the positive effect of monetary easing on unexpected excess Treasury bond returns mainly results from downward revisions in inflation expectations. These main findings are robust to various sensitivity checks, including the use of survey-based inflation expectations. 
Our analysis is related to three strands of the literature. The first strand includes studies that assess the role of macroeconomic forces, most importantly inflation, in determining bond market volatility. The significance of inflation risk for nominal bonds within prominent term structure models varies considerably from very high (Piazzesi and Schneider; 2007) to almost zero (Chernov and Mueller; 2012). The term structure literature does not allow one to draw widely accepted conclusions about the joint dynamics of inflation and the nominal term structure (Duffee, 2017). Different restrictions on risk premium dynamics may play a role in explaining these differences. Our findings about the important role of inflation news are consistent with C/A and other studies that use their model in the US (Engsted and Tanggaard, 2007) and other countries (Barr and Pesaran, 1997; Cenedese and Malluci, 2015). They are in contrast, however, to Duffee (2017) who identifies inflation news using survey data and finds that the variance of news about expected inflation explain only between 10 to 20 percent of the variance of shocks to nominal Treasury yields.

The differences between the results of studies that use C/A's approach and Duffee (2017) are likely to driven to driven by different modelling approaches and assumptions regarding the identification of inflation news. In the C/A framework inflation enters the model indirectly as part of the construction of the ex post real interest rate, and inflation news are identified using yields' data - see Section 2.2 for more details. The findings of Coibion and Gorodnichenko (2012) suggest that behaviour of survey-based inflation forecasts, such as those used by Duffee (2017), is consistent with the presence of information rigidities. Stickiness in survey-based forecasts implies that they may differ from the inflation expectations of investors, as built in bond prices and yields, since the latter are more likely to be frequently updated. In an earlier working paper version, Duffee (2014) acknowledges that the non-volatile nature of survey-based inflation expectations is crucial in generating a weaker role for inflation in the variance decomposition: "Although expectations of future inflation are highly persistent, they 
fluctuate little over time... Thus mechanically, innovations to expected short-term real rates and term premia are the primary drivers of yield shocks" (Duffee, 2014; p.2). ${ }^{3}$

The second strand of related literature considers the bond market effects of monetary policy shocks. Two key findings from earlier studies, conducted prior to the 2007-2009 financial crisis, are that Treasuries significantly respond to shifts in the FFR and the response tends to diminish at longer maturities (Kuttner, 2001; Cochrane and Piazzesi, 2002). Following the onset of the financial crisis, the implementation of QE led to a surge of studies that examine its impact on the bond market. Using various approaches, it is commonly found that QE was effective in reducing long-term Treasury bond yields. As to how this was achieved, the existing literature emphasizes two potential channels. According to the signalling channel, QE provided information to market participants about the commitment of the Fed to easier monetary policy, leading to lower expectations of future short-term rates. This development explains, through the expectations theory of the term structure, the reduction in long-term yields. On the other hand, the portfolio balance channel assumes imperfect substitutability of bonds with different maturities, consistent with preferred habitat investors (Vayanos and Vila, 2009). According to it, the QE-induced decline in the supply of long-term bonds reduced their yield by compressing the term premium. ${ }^{4}$ The evidence in this paper is overall not supportive for the portfolio balance mechanism's prediction of a strong role for risk premium news in explaining the bond market reaction to the expanding balance sheet of the Fed.

The third strand of related literature examines the effect of monetary policy shocks on inflation expectations. The negative impact of monetary easing on inflation expectations

\footnotetext{
${ }^{3}$ Bridging both approaches, one could argue that Duffee's results, which rely on the use of highly persistent survey-based expectations, might be interpreted as a lower bound for the importance of inflation news. On the other hand, our market data-based results might be seen as the corresponding upper bound.

${ }^{4}$ The empirical evidence is rather mixed. For example, Gagnon et al. (2011) and D'Amico et al. (2012) support a term-premium explanation, while Bauer and Rudebusch (2013) favour the signalling channel. The mixed empirical evidence together with the empirical failure of the expectations theory (Thornton, 2005; Sarno et al., 2007) and the restrictive theoretical assumptions underlying preferred habitat (Thornton, 2012) imply that our understanding of how QE led to lower bond yields is still incomplete.
} 
appears counter-intuitive when viewed through the lens of standard macroeconomic models where expansionary shocks are associated with a rise in inflation and inflation expectations. ${ }^{5}$ However, as Andreou et al. (2017) point out, recent theoretical work suggests different impact of monetary policy on inflation expectations depending on the theoretical model being considered (Cochrane, 2016; Garcia-Scmhidt and Woodford, 2015; Campbell et al., 2012). In contrast to standard "textbook" models, imperfect information-based approaches, such as in Campbell et al. (2012), and the neo-Fisherian model of Cochrane (2016) suggest that if the Fed increases the policy rate, inflation expectations will rise. Imperfect information-based approaches assume that the Fed has superior information relative to the private sector. ${ }^{6}$ Our findings regarding the link between monetary policy and inflation expectations are broadly in line with the survey-based empirical evidence in Campbell et al. (2012) for the US.

The rest of the paper is structured as follows. Section 2 presents the methodology. Section 3 describes the dataset. Section 4 contains the empirical results from the baseline analysis, while Section 5 contains the robustness checks. Section 6 concludes.

\section{Methodology}

\subsection{Excess bond returns decomposition}

Using the framework of C/A, we decompose current period unexpected excess bond returns into revisions in expectations about future one-period excess bond returns $(x)$, inflation $(\pi)$ and real interest rates $\left(r^{i}\right)$ :

\footnotetext{
${ }^{5}$ Nevertheless, previous evidence indicates it takes several quarters for inflation to respond to monetary policy shocks and a "price puzzle" may occur in the short-run (Rusnak et al., 2013). A related reason why our results may look to be at odds with the VAR literature is that identified VAR analyses often restrict responses of key endogenous variables to be "theory-consistent". Uhlig (2005) shows that monetary shocks have no effect on GDP when he imposes no restrictions on that relationship.

${ }^{6}$ This may be related to the superior resources that it commits to forecasting (Romer and Romer, 2000).
} 


$$
\ell_{n, t+1}=\left(E_{t+1}-E_{t}\right)\left[-\sum_{j=1}^{n-1} x_{n-j, t+1+j}-\sum_{j=1}^{n-1} \pi_{t+1+j}-\sum_{j=1}^{n-1} r_{t+1+j}^{i}\right]=-\varnothing_{x, t+1}-\varnothing_{\pi, t+1}-\varnothing_{r^{\prime}, t+1}
$$

where $\ell_{n, t+1}=x_{n, t+1}-E_{t}\left[x_{n, t+1}\right]$ represents the unexpected one-period log return on a $n$-period zero-coupon bond in excess of the continuously compounded one-period nominal interest rate, $\ell_{x, t+1}^{o}$ denotes revisions in expectations regarding future excess bond returns (risk premium news), $\ell_{\pi, t+1}$ represents revisions in expectations about future inflation (inflation news) and $\ell_{r^{\prime}, t+1}$ denotes revisions in expectations regarding future real interest rates (real interest rate news). ${ }^{7}$ This decomposition implies that positive unexpected excess bond returns must be associated with decreases in expected future excess returns during the life of the bond, decreases in expected future inflation rates, decreases in expected future real interest rates, or a combination of the three.

Equation (1) is a dynamic accounting identity that arises from the definition of bond returns. While it is not a behavioural model containing economic theory and asset pricing assumptions, both the Fisher hypothesis and the expectations theory of the term structure have important implications for the decomposition of excess bond returns. Specifically, the former hypothesis implies that ex ante real interest rates are constant and therefore the real interest rate news term is zero. The latter hypothesis assumes time-invariant expected excess bond returns which are consistent with the risk premium news term being zero. Therefore, in the extreme, if both hypotheses hold, inflation news will be the only source of variation in bond returns in excess of the short-term risk-free rate. ${ }^{8}$

\footnotetext{
${ }^{7}$ See Online Appendix A for the derivation.

${ }^{8}$ Existing evidence regarding the empirical validity of the expectations hypothesis and the Fisher hypothesis can be described as mixed with the role of the adopted testing procedures being crucial. Sarno et al. (2007) use a more powerful test with either macroeconomic factors or more than two bond yields and overturn evidence from conventional tests by showing that the expectations hypothesis can be rejected throughout the maturity spectrum. Christopoulos and Leon-Ledesma (2007) attribute the lack of widespread empirical evidence for the Fisher hypothesis in cointegration-based studies to non-linearities in the long-run relationship between nominal interest rates and inflation.
} 
It is of great interest to examine the relative shares of the three news components in explaining the variability of unexpected excess returns. This is especially important from the perspective of monetary policy makers at times when unconventional policy tools are used to reduce longer-term interest rates. From Equation (1) it follows that the total variance of excess returns can be decomposed into the sum of the three variances plus the respective covariance terms:

$$
\begin{aligned}
& \operatorname{Var}\left(\ell_{n, t+1}^{o}\right)=\operatorname{Var}\left(\ell_{x, t+1}^{o}\right)+\operatorname{Var}\left(\ell_{\pi, t+1}^{o}\right)+\operatorname{Var}\left(\ell_{r^{\prime}, t+1}\right)+2 \operatorname{Cov}\left(\ell_{x, t+1}^{o}, \ell_{\pi, t+1}^{o}\right) \\
& +2 \operatorname{Cov}\left(\varnothing_{x, t+1}, \varnothing_{r^{\prime}, t+1}\right)+2 \operatorname{Cov}\left(\varnothing_{r^{i}, t+1}, \varnothing_{T, t+1}\right)
\end{aligned}
$$

In order to evaluate the relative importance of news about risk premium, inflation and real interest rates, we normalise each of the variance and covariance terms in Equation (2) by the total variability of excess returns.

\section{$2.2 \quad$ Vector autoregressive model and news}

The implementation of the variance decomposition for excess bond returns requires empirical proxies for the non-directly observable revisions in expectations regarding future excess returns, inflation and real interest rates. C/A's methodology links these multiperiod expectations to the stationary dynamics of a vector autoregressive model. Specifically, a firstorder VAR is employed, involving the variables of interest along with other indicators that may be useful in forecasting them, to obtain empirical proxies for the news components in Equation (1). The forecast residuals and the estimated parameters from the VAR model are used to construct time series of revisions in expectations for the variables of interest. The starting point is the definition of a state vector containing stationary variables that help to measure or forecast excess bond returns, inflation and real interest rates:

$$
Z_{t+1}=A Z_{t}+W_{t+1}
$$


where $Z_{t}$ is a vector of endogenous state variables included in the model, $A$ denotes a matrix of VAR parameters, and $W_{t}$ is a vector of forecast errors. The state vector includes the change in the nominal short-term risk-free rate, $\Delta y_{1, t}$; the spread between long-term and short-term yields, $s_{n, t}$; the real interest rate, $r_{t}^{i}$; the relative bill rate, $r b_{t}$, i.e. the difference between the nominal short-term interest rate and its 12-month backwards moving average.

The first two variables in the state vector are used to construct innovations in excess bond returns. The term spread has strong predictive power over bond returns (Campbell and Shiller, 1991; Fama and Bliss, 1987; Greenwood and Vayanos, 2014), while the relative bill rate is a forecasting variable that can capture longer-run dynamics of interest rate changes without introducing long lags (C/A; Barr and Pesaran, 1997; Bernanke and Kuttner, 2005). The VAR estimates allow us to compute unexpected excess bond returns and the three components identified in Equation (1) as follows:

$$
\begin{aligned}
& \ell_{n, t+1}=-(n-1)\left(s_{1}^{T} W_{t+1}+s_{2}^{T} W_{t+1}\right) \\
& \underset{r^{\prime}, t+1}{\varnothing_{3}}=s_{3}^{T}(I-A)^{-1}\left(A-A^{n}\right) W_{t+1}, \\
& \varnothing_{\pi, t+1}^{\varnothing_{1}}=s_{1}^{T}\left\{(I-A)^{-1}\left[(n-1) I+(I-A)^{-1}\left(A^{n}-A\right)\right]\right\} W_{t+1}-\varnothing_{r^{\prime}, t+1}, \\
& \ell_{x, t+1}=-\ell_{n, t+1}-\varnothing_{r^{\prime}, t+1}-\varnothing_{\pi, t+1}
\end{aligned}
$$

where $n$ refers to the maturity of a bond ( $n$-period bond), $s_{i}^{T}$ is a unit vector with $i$ representing $i^{\text {th }}$ equation in the model and accordingly the $i^{\text {th }}$ element of a vector is set to 1 ; $I$ is the identity matrix. ${ }^{9}$

Equation (4) shows that current unexpected excess bond returns are obtained using innovations in the change of the nominal short-term rate and the term spread. The inclusion of

\footnotetext{
${ }^{9}$ See Online Appendix B for more details.
} 
the real interest rate in the state vector allows the extraction of news about it directly from the VAR model as indicated by Equation (5). In Equation (6), the inflation news term is computed by combining innovations in the change of the nominal short-term rate with news about real interest rates. Finally, Equation (7) shows that risk premium news is obtained as a residual using the dynamic accounting identity and the estimates of the other components. ${ }^{10}$

\subsection{Monetary policy effects}

The above sections explain how the variation of the unexpected excess bond returns can be linked to news about future excess returns, inflation and real interest rates, and how these news terms can be obtained from a VAR model. In this section we present the framework that we use to estimate the impact of monetary policy actions on the bond market. To do so, we modify Bernanke and Kuttner's (2005) extension of C/A's methodology for the case of the bond market. Our approach generates estimates of the impact of monetary policy shocks on unexpected excess bond returns and the related news terms, thereby providing insights to sources of the bond market's response to monetary policy. The starting point is the inclusion of a monetary policy shocks indicator $(M P)$ as an exogenous variable in the VAR model:

$$
Z_{t+1}=A Z_{t}+\phi M P_{t+1}+W_{t+1}^{*}
$$

where $\phi$ is a vector that includes the state variables' response parameters to contemporaneous monetary policy actions. We proceed by estimating the original VAR model to obtain estimates of $A$ and then regress the forecast residuals on the monetary policy indicator variable in order to estimate $\phi .{ }^{11}$ The monetary policy effect on the current unexpected excess

\footnotetext{
${ }^{10} \mathrm{As} \mathrm{C} / \mathrm{A}$ explain, backing out risk premium news as a residual is necessary for zero-coupon bonds since shrinking maturity over the life of a bond precludes the direct forecasting of excess returns using the VAR model.

${ }^{11}$ The new error term $\left(W_{t+1}^{*}\right)$ is by construction orthogonal to the monetary policy shocks indicator. Essentially, the VAR's 1-month-ahead forecast error $\left(W_{t+1}\right)$ is split into a component related to news about monetary policy $\left(\varphi M P_{t+1}\right)$ and a component incorporating information about things other than policy: $W_{t+1}=\varphi M P_{t+1}+W_{t+1}^{*}$. The aforementioned system of equations is estimated at an equation-by-equation basis using OLS as in Maio (2014).
} 
returns and news about real interest rates, inflation and the risk premium can be computed using Equations (9)-(12), respectively:

$$
\begin{aligned}
& \mathcal{X}_{n, t+1}^{M P}=-(n-1)\left(s_{1}^{T}+s_{2}^{T}\right) \phi \\
& \underset{r^{i}, t+1}{M P P}=s_{3}^{T}(I-A)^{-1}\left(A-A^{n}\right) \phi \\
& \ell_{\pi, t+1}^{M P}=s_{3}^{T}(I-A)^{-1}\left(A-A^{n}\right) \phi+s_{1}^{T}\left\{(I-A)^{-1}\left[(n-1) I+(I-A)^{-1}\left(A^{n}-A\right)\right]\right\} \phi \\
& \ell_{x, t+1}^{M P}=-\bigotimes_{n, t+1}^{M P}-\bigotimes_{\frac{\pi}{\pi}, t+1}^{M P}-\ell_{r^{i}, t+1}^{M P}
\end{aligned}
$$

\section{Data and variables}

\subsection{Sample period}

We use monthly data over the period 1985:1 - 2014:2 for the VAR estimation. The sample commences during the early years of the Great Moderation period, while its latter part contains the recent global financial crisis and its aftermath. Our analysis is conducted over both the full sample period and a shorter sample that ends prior to the onset of the recent financial crisis. Doing so, we get insights about the impact of crisis on the variance decomposition of unexpected excess bond returns and the relationship between monetary policy actions and bond returns. Note that due to the later availability of FFR futures data, the starting point of the sample in the estimations of conventional monetary policy effects, identified using unexpected changes in the FFR, is 1989:2.

\subsection{VAR state variables}

We use the 1-month Treasury bill rate, obtained from the Centre for Research in Security Prices (CRSP), as a proxy for the nominal short-term risk-free interest rate $\left(y_{1, t}\right)$. The 
long-short spread $\left(s_{n, t}\right)$ is calculated as the difference between 10-, 5-, and 2- year zero-coupon Treasury bond yields and $y_{1, t}$. Data on continuously compounded zero-coupon yields is obtained from the daily dataset provided by Gurkaynak et al. (2007). The ex post real interest rate is defined as the difference between $y_{1, t-1}$ and the current monthly inflation rate, measured by the change in the log of the seasonally adjusted CPI All items index. CPI data is provided by the Federal Reserve Bank of St Louis (FREDII database). The relative bill rate is the deviation of $y_{1, t}$ from its 12-month backwards moving average. All state variables are demeaned prior to estimations and expressed in percentages per annum on continuously compounded basis (end of month data used).

\subsection{Monetary policy shocks indicators}

During the Great Moderation era, monetary policy conduct has been characterised by FFR targeting and increasing transparency. The financial crisis of 2007-2009 brought this benign regime to an end and had a significant impact on the Fed's approach to monetary policy implementation. The Fed responded aggressively to the crisis by reducing the target FFR to near zero. Moreover, it used various tools (liquidity facilities and Large Scale Asset Purchases (LSAPs)) to improve financial market conditions and put downward pressure on longer-term interest rates, thereby supporting economic activity. ${ }^{12}$ Conducting the LSAPs programme, the Fed purchased significant amounts of longer-term assets from the private sector, mainly Treasury bonds and agency mortgage backed securities, leading to significant changes in the size and composition of its balance sheet. ${ }^{13}$ The increase in the Fed's assets was matched by an expansion in its liabilities. Particularly, reserve balances have increased considerably relative to their level prior to the financial crisis and are highly in excess of the regulatory requirements.

\footnotetext{
12 See Table C2 in Online Appendix C for a list of the relevant announcements by the Fed.

${ }^{13}$ Figure $\mathrm{C} 2$ in Online Appendix C shows developments in the Fed's holdings of Treasury securities across different maturities.
} 
Figure 1 shows the dramatic rise in total reserves and the monetary base since late 2008 and also highlights that, in contrast to narrow money, broad money (M2) did not significantly expand.

\section{[FIGURE 1 HERE]}

In our empirical analysis we use two monetary policy shocks indicators that are related to unexpected changes in the FFR and the (log) monetary base. Conventional monetary policy is captured by the FFR-based measure, while non-conventional policy dimensions are captured by the quantity-based measure. The first indicator isolates surprise FFR changes using data from FFR futures and the methodology of Kuttner (2001). The month- $t$ unexpected FFR change, $\Delta F F R_{t}^{U}$, can be calculated as follows:

$$
\Delta F F R_{t}^{U}=\frac{1}{D} \sum_{d=1}^{D} i_{t, d}-f_{t-1, D}^{1}
$$

where $i_{t, d}$ denotes the target FFR on a day $d$ of month $t$, and $f_{t-1, D}^{1}$ is the rate corresponding to the 1-month futures contract on the last $\left(D^{t h}\right)$ day of month $t-1$. The definition is based on that the FFR futures contract's settlement price is determined by the monthly average FFR. ${ }^{14}$

The second indicator measures monetary shocks using unexpected changes in the log of the seasonally adjusted (St. Louis adjusted) monetary base (MB), $\Delta M B_{t}=M B_{t}-M B_{t-1}$. The use of quantity-based indicators is motivated by several recent theoretical studies that evaluate the role of the monetary base, or the supply reserves, as an alternative operating target for monetary policy (Curdia and Woodford, 2011; Gertler and Karadi, 2013).A number of empirical studies that focus on the Japanese QE experience use developments in narrow money as proxy for nonconventional monetary policy (Harada and Masujima, 2009). Developments in the monetary base should be more informative, as compared to asset-side measures, about the Fed's nonconventional policies. This is because asset-side proxies just reflect LSAPs and show

\footnotetext{
${ }^{14}$ FFR data is obtained from the FREDII database, while Bloomberg is the source of FFR futures data..
} 
significant activity only since early 2009 , while monetary base changes further capture the impact of the various non-sterilised liquidity facilities of the Fed that were heavily used in autumn 2008..$^{15}$

In line with previous work by Cover (1992) and Karras (2013), we obtain surprises in narrow money growth, $\Delta M B_{t}{ }^{U}$, as the residuals from a regression of monetary base growth on its own lags and lags of unemployment:

$$
\Delta M B_{t}=a+\sum_{j=1}^{n} \beta_{j} \Delta M B_{t-j}+\sum_{i=1}^{m} \gamma_{i} U N_{t-i}+\varepsilon_{t}
$$

where $U N_{t}=\log \left[U_{t} /\left(1-U_{t}\right)\right]$ and $U_{t}$ denotes unemployment. ${ }^{16}$ Figure 2 plots the two monetary policy shocks indicators. Towards the end of 2008, the quantity-based proxy becomes highly active while the volatility of interest rate-based proxy displays a negative trend over time and dies out since the zero lower bound was reached.

\section{[FIGURE 2 HERE]}

The indicator for monetary policy shocks is included as an exogenous variable in Equation (8). The exogeneity assumption would not hold if the Fed responds contemporaneously to developments in the market for Treasuries and if the Fed and the Treasuries market jointly and contemporaneously respond to new economic information. With respect to the first potential source of endogeneity, empirical evidence on whether the Fed is systematically following Treasuries is overall non-conclusive and rather elusive when medium and longer term yields are examined (Nimark, 2008). Second, in order to examine whether the policy shocks indicators contemporaneously react to economic news, we regress them on variables that capture surprises in nonfarm payrolls, industrial production growth, retail sales

\footnotetext{
${ }^{15}$ Indeed, the highest monetary base growth rates in US record occurred in October and November 2008 reaching $20 \%$ and $26 \%$ per month, respectively.

${ }^{16}$ The number of lags $(n=m=7)$ is chosen by the Akaike information criterion.
} 
growth, core and headline CPI inflation (Bernanke and Kuttner, 2005). We do not find a significant contemporaneous monetary policy response to macroeconomic surprises. ${ }^{17}$ Finally, in the robustness checks section we address the issue of potential endogeneity using the approach of Romer and Romer (2004) to calculate policy shocks that take into account the Fed's response to expected economic conditions. We find that the main results hold. Hence, the exogeneity assumption should not be significantly restrictive in the context of our analysis.

\section{Empirical findings}

\subsection{VAR estimation results}

Table 1 reports the estimated VAR(1) coefficients for the full and pre-crisis sample periods for three alternative VAR models that only differ in terms of the zero-coupon bond yield used to calculate the long-short spread (10-, 5- and 2-year yields). Heteroskedasticityconsistent standard errors are shown in parentheses. The results can be summarised as follows. First, the one-month ahead forecasting power of the VAR is quite reasonable. Second, the change in the nominal short-term rate is predicted by its own lag, the lagged long-short spread and the lagged relative bill rate. The long-short spread is highly persistent with its autoregressive coefficient being close to $0.8-0.9$ across the different cases. The real interest rate typically follows an $\mathrm{AR}(1)$ process with a coefficient of about 0.4 to 0.5 . The lagged spread generally helps to forecast the real rate in the case of 10-year and 5-year bonds. The relative bill rate is forecast by its own lag, the lagged spread and the lagged change in the nominal shortterm rate. Third, the one-period dynamics of the system are not significantly affected by the inclusion of the financial crisis in the sample period. Fourth, the estimated VARs are dynamically stable since no root lies outside the unit circle.

\footnotetext{
${ }^{17}$ Due to data availability, the sample period for these regressions starts in 1991:10. See Table C3 in Online Appendix $\mathrm{C}$ for the results.
} 


\section{[TABLE 1 HERE]}

\subsection{Variance decomposition results}

The variance decomposition results for 10-, 5- and 2-year bonds are shown in Table 2. In addition to the variances and covariances of the three components of unexpected excess bond returns, normalised by the variance of the return innovation itself, we report the $\mathrm{R}^{2}$ statistics from univariate regressions of unexpected excess returns on each of the estimated components. The key finding in Table 2 is that across different maturities news about future inflation is the dominant factor in explaining the variation of Treasury bond returns. For example, the full sample variance decomposition attributes $83 \%$ of the variance of 10 -year bond excess returns innovations to the variance of inflation news. Both the volatility of inflation news and that of unexpected excess Treasury bond returns decrease as we move from longer-term to shorterterm bonds, but the latter's decrease is more pronounced. Hence, the ratio of the volatility of inflation news to the volatility of unexpected excess bond returns is higher for shorter-term bonds.

When we exclude the recent financial crisis and its aftermath from the sample that is used for the VAR estimation, we obtain variance decompositions that are similar to the full sample. This finding is consistent with the fact that the VAR estimation results in Table 1 do not indicate significant changes across the two samples in the predictability of the components of excess bond returns. The dominant role of inflation is also highlighted by the high $\mathrm{R}^{2}$ values in regressions of returns innovations on inflation news. On the other hand, estimates of the risk premium and real interest rate news variance terms are typically smaller in magnitude and statistically insignificant, while the covariances also play a minor role in the decomposition. The importance of inflation news is consistent with previous evidence for the US by studies that include the highly inflationary 1970 s and early 1980 s and use C/A's approach to extract news (C/A; Engsted and Tanggaard, 2007; Bredin, Hyde and O'Reilly, 2010). Moreover, the 
relevant magnitudes in Table 2 are in line those with previous studies. For example, the $\mathrm{R}^{2}$ associated with inflation news in long-term government bonds is $85 \%$ in Engsted and Tanggaard (2007), while for 10-year bonds in our full sample it equals $80 \%$.

[TABLE 2 HERE]

\subsection{Monetary policy effects on unexpected excess returns and their components}

Tables 3-4 report estimates of the impact of monetary policy shocks on unexpected excess Treasury bond returns and their components over the full and pre-crisis sample periods. The results in Table 3 are based on unexpected FFR changes. Several interesting features arise. First, we find that monetary policy shocks significantly affect the bond market across all three maturities and across both sample periods. In particular, monetary easing shocks (unexpected FFR cuts) are associated with higher contemporaneous unexpected excess returns. Second, the impact of FFR shocks on bond returns tends to increase in magnitude, particularly in the precrisis period, as the maturity increases. There are various possible explanations for the significant reaction at the long-end of the bond market. Rolley and Sellon (1995) point out that if policy actions are seen as relatively permanent or as the first in a series of future actions, the response of long-term rates may be larger than the response of short-term rates. Over-reaction of long-term rates to changes in short rates could also provide a mechanism to explain the impact of monetary policy throughout the term structure (Romer and Romer, 2000). Ang et al. (2011), on the other hand, emphasise the role of shifts in the Fed's policy reaction function.

Third, the reaction of the bond market to monetary policy actions is largely explained through the inflation news channel. Specifically, we find that the key driver of the positive bond returns' response to unexpected FFR cuts is their negative effect on inflation expectations. The effect is stronger at longer maturities, especially when we use the pre-crisis sample. Fourth, while reductions in the FFR exert a large and statistically significant effect on inflation expectations, the impact on expected excess bond returns (term premium) and real interest rates 
is typically smaller or insignificant. Only in the case of full sample estimates for 10-year bonds the risk premium news and real interest rate news responses are statistically significant at the $5 \%$ level. The positive effect of monetary easing on real interest rate news is outweighed by the negative effect on the other two components of unexpected excess bond returns (inflation and risk premium news), so that the total effect on bond returns is positive.

\section{[TABLES 3-4 HERE]}

Table 4 uses unexpected changes in the $(\log )$ monetary base. We focus on the full sample estimation results since the pre-crisis sample excludes the recent financial crisis and its aftermath, that is, the period when quantity-based indicators became strongly active due to the non-conventional policies that were adopted by the Fed. The main insights that we identified using interest rate-based measures remain overall valid in full sample estimations with quantitybased measures. Particularly, the positive effect of monetary easing shocks (higher unexpected monetary base growth) on unexpected excess Treasury bond returns comes through downward revisions in inflation expectations, with the impact being generally stronger at longer maturities. The full sample results indicate that money growth surprises significantly affects real interest rate expectations, whereas the impact on risk premium news tends to be statistically insignificant. The positive effect of monetary easing on real interest rate news is compensated by the negative impact on inflation news.

\section{[FIGURE 3 HERE]}

Comparing the full sample with the pre-crisis results from quantity-based measures of monetary policy, it becomes apparent that the former largely reflect developments that occurred during the financial crisis. Following the collapse of Lehman Brothers the Fed significantly expanded the pace of monetary easing, both in the conventional and non-conventional sense. The FFR declined by 160 basis points between September-November 2008 and the monetary base growth rate recorded historical highs due to the heavy usage of non-sterilised Fed liquidity 
facilities. At the same time, inflation expectations declined sharply in line with the worsening economic outlook (Campbell, Shiller and Viceira, 2009). To gain further insight into the possibility of a structural change in the bond market's reaction to quantity-based measures of monetary policy, we turn to recursive estimation. Figure 3 plots recursive estimates of the response parameters of unexpected excess Treasury bond returns and the corresponding inflation news component to unexpected changes in log monetary base. These highlight the presence of an important structural shift which took place in autumn 2008. Following the unprecedented expansion in the monetary base (see Figure 1) and the announcement of QE1, the relationship between money growth surprises and bond returns tends to increase in magnitude. At the same time, the impact of money growth surprises on inflation expectations becomes strongly negative, consistent with downward revisions to inflation expectations in response to monetary easing. The response parameters exhibit a tendency to become smaller in size after the initial shock, suggesting that further rounds of QE may not have been as influential as the first one. Thus, the recursive estimates confirm that the differences between the full sample and pre-crisis sample estimates of the effects of money growth surprises are largely driven by crisis-period developments.

Summarising our main results, we find that the positive effect of monetary easing on the Treasury bond market is principally due to falls in inflation expectations. The negative impact of monetary easing on inflation expectations is somewhat counterintuitive, however it is consistent with previous studies that use surveys to measure expectations. Monetary policy surprises may contain a significant "Delphic" component that reveals policy makers' view on future macroeconomic performance together with intended monetary policy actions (Campbell et al., 2012). In this case, expansionary monetary policy shock could lead to negative revisions to inflation expectations by professional forecasters if central banks' forecasts are perceived as being superior to publicly available information. Several other studies find evidence in line with 
"Fed information effects" (Romer and Romer, 2000; Nakamura and Steinsson, 2018). Similarly, Andreou et al. (2017) show that imperfect information about macroeconomic variables held by consumers also can explain downward revisions to consumer inflation expectations in response to expansionary monetary policy shock. Our results are also consistent with the way that financial market participants routinely interpret monetary policy actions, with easing often seen as signalling a worsening economic outlook. ${ }^{18}$ Finally, our results are overall not supportive of the portfolio balance mechanism, according to which monetary easing, via an expansion of the Fed's balance sheet, should increase current period bond returns primarily through downward adjustments in expected excess returns (term premium).

\section{Robustness checks}

We examine the sensitivity of our empirical findings in a number of ways and find that the results are robust. First, we extend the state vector specification of the underlying VAR model. Second, we employ the methodology suggested by Romer and Romer (2004) to calculate monetary policy shocks. Third, we consider higher-order VARs. Fourth, we modify the model that is used to extract monetary base growth surprises. Fifth, we consider alternative quantity-based monetary policy indicators. Finally, we estimate the effect of monetary policy shocks on inflation news identified from surveys. The results are contained and discussed in the Online Appendix C.

\section{Conclusions}

Following the recent financial crisis and the actions taken by the Fed, analyses of the bond market impact of monetary policy actions came to the focus of academics, investors and

\footnotetext{
${ }^{18}$ See, e.g., the following excerpt from the Financial Times (2/2/2001): "Government bond prices rose yesterday as markets around the world digested Wednesday's 50 basis points interest rate cut by the US Federal Reserve...slower growth and less inflation was good for the bond market...".
} 
policymakers. This paper combines the dynamic accounting identity of C/A with a VAR model to decompose unexpected excess bond returns in news about future excess returns, inflation and real interest rates, and links these with policy shocks. FFR-based indicators are used to capture conventional monetary policy, whereas shifts in the monetary base are employed to capture the non-conventional dimensions of monetary policy during the crisis and its aftermath.

We find that monetary easing is associated with higher bond returns. In the case of quantity-based monetary policy indicators, the bond market response largely reflects developments that occurred at the peak of the financial crisis in autumn 2008. As to why the bond market responds in this manner, the results highlight the role of inflation news. We find that the positive effect of monetary easing on bond returns mainly comes from corresponding downward revisions in inflation expectations. Such a link between monetary policy shocks and inflation expectations is consistent with "Fed information effects" (Romer and Romer, 2000; Nakamura and Steinsson 2018). 


\section{References}

Andreou, E., Eminidou, S., and Zachariadis, M., 2017. Inflation expectations and monetary policy surprises. University of Cyprus, Department of Economics, Working paper 012017.

Ang, A., Boivin, J., Dong, S., and Loo-Kung, R., 2011. Monetary policy shifts and the term structure. Review of Economic Studies, 78(2), p.429-457.

Barr, D., and Pesaran, B., 1997. An assessment of the relative importance of real interest rates, inflation, and term premiums in determining the prices of real and nominal U.K. bonds. Review of Economics and Statistics, 79(3), p.362-366.

Bauer, M.D., and Rudebusch, G.D., 2013. The signaling channel for Federal Reserve bond purchases. Federal Reserve Bank of San Francisco Working Paper Series, Working paper 2011-21.

Bernanke, B.S., and Kuttner, B.N., 2005. What explains the stock market's reaction to Federal Reserve policy? Journal of Finance, 60(3), p.1221-1257.

Bredin, D., Hyde, S., and O'Reilly, G., 2010. Monetary policy surprises and international bond markets. Journal of International Money and Finance, 29(6), p.988-1002.

Campbell, J.Y., 1991. A variance decomposition for stock returns. Economic Journal, 101(405), p.157-179.

Campbell, J. Y., and Ammer, J., 1993. What moves the stock and bond markets? A variance decomposition for long term asset returns. Journal of Finance, 48(1), p.3-37.

Campbell, J.Y., Lo, A.W., and MacKinlay, A.C., 1997. The econometrics of financial markets. New Jersey: Princeton University Press.

Campbell, J.Y., and Shiller, R.J., 1988. The dividend-price ratio and expectations of future dividends and discount factors. Review of Financial Studies, 1(3), p.195-228. 
Campbell, J.Y., and Shiller, R.J., 1991.Yield spreads and interest rate movements: A bird's eye view. Review of Economic Studies, 58(3), p.495-514.

Campbell, J.Y., Shiller, R.J., and Viceira, L.M., 2009. Understanding inflation-indexed bond markets. NBER Working Paper Series, Working paper 15014.

Campbell, J.R., Evans, C.L., Fisher, J.D., and Justiniano, A., 2012. Macroeconomic effects of Federal Reserve forward guidance. Brooking Papers on Economic Activity, Spring 2012.

Cenedese, G., and Mallucci, E., 2015. What moves international stock and bond markets? Journal of International Money and Finance, forthcoming.

Chen, S., 2007. Does monetary policy have asymmetric effects on stock returns? Journal of Money, Credit and Banking, 39(2-3), p.667-688.

Chernov, M, and Mueller, P., 2012. The term structure of inflation expectations. Journal of Financial Economics, 106(2), p.367-394.

Christopoulos, D.K., and Leon-Ledesma, M.A., 2007. A long-run non-linear approach to the Fisher effect. Journal of Money, Credit, and Banking, 39(2-3), p.543-559.

Cochrane, J.H., 2016. Do higher interest rates raise or lower inflation? Paper posted at http://faculty. chicagobooth.edu/john.cochrane/research/papers/fisher.pdf.

Cochrane, J.H., and Piazzesi, M., 2002. The Fed and interest rates: A high-frequency identification. American Economic Review Papers and Proceedings, 92(2), 90-95.

Coibion, O., and Gorodnichenko, Y., 2012, What can survey forecasts tell us about informational rigidities. Journal of Political Economy, 120(1), p.116-159.

Cover, J.P., 1992. Asymmetric effects of positive and negative money-supply shocks. Quarterly Journal of Economics, 107(4), p.1261-1282.

Curdia, V., and Woodford, M., 2011. The central-bank balance sheet as an instrument of monetary policy. Journal of Monetary Economics, 58(1), p.54-79. 
D'Amico, S., English, W., Lopez-Salido, D., and Nelson, E., 2012. The Federal Reserve's largescale asset purchase programmes: rationale and effects. Economic Journal, 122(564), p.415-446.

Duffee, G.R., 2014. Expected inflation and other determinants of Treasury yields. Johns Hopkins University, Working paper.

Duffee, G.R., 2017. Expected inflation and other determinants of Treasury yields. Journal of Finance, forthcoming.

Engsted, T., and Tanggaard, C., 2007. The comovement of U.S. and German bond markets. International Review of Financial Analysis, 16(2), p.172-182.

Fama, E.F, and Bliss, R., 1987. The information in long-maturity forward rates. American Economic Review, 77(4), p. 680-692.

Fricke, C., and Menkhoff, L., 2014. Financial conditions, macroeconomic factors and (un)expected bond excess returns. Deutsche Bundesbank, discussion paper 35/2014.

Gagnon, J., Raskin, M., Remache, J., and Sack, B., 2011. Large-scale asset purchases by the Federal Reserve: did they work? Federal Reserve Bank of New York Economic Policy Review, 17(1), p.41-59.

Garcia-Schmidt, M., and Woodford, M., 2015 Are low interest rates deflationary? A paradox of perfect foresight analysis. NBER Working Paper Series, Working paper 21614.

Gertler, M., and Karadi, P., 2013. QE 1 vs. 2 vs. 3. . . : A Framework for analyzing large-scale asset purchases as a monetary policy tool. International Journal of Central Banking, 9(1), p.5-53.

Greenwood, R., and Vayanos, D., 2014. Bond supply and excess bond returns. Review of Financial Studies, 27(3), p.663-713. 
Gurkaynak, R.S., Sack, B., and Wright, J.H., 2007. The U.S. treasury yield curve: 1961 to the present. Federal Reserve Board Finance and Economics Discussion Series, Working paper 2006-28.

Harada, Y., and Masujima, M., 2009. Japanese Economy, 36(1), p.48-105.

Hansen, P., 2006. A test for superior predictive ability. Journal of Business and Economic Statistics, 23(4), p. 365-80.

Karras, G., 2013. Asymmetric effects of monetary policy with or without quantitative easing: empirical evidence for the US. Journal of Economic Asymmetries, 10(1), p.1-9.

Kuttner, K.N., 2001. Monetary policy surprises and interest rates: evidence from the fed funds futures market. Journal of Monetary Economics, 47(3), p.523-544.

Ludvigson, S.C., and Ng, S., 2009. Macro factors in bond risk premia. Review of Financial Studies, 22(12), p.5027-5067.

Maio, P., 2014. Another look at the stock return response to monetary policy actions. Review of Finance, 18(1), p.321-371.

Mankiw, N. G., and Reis, R., 2002. Sticky information versus sticky prices: A proposal to replace the New Keynesian Phillips curve.” Quarterly Journal of Economics, 117(4), p.1295-1328.

Nakamura, E., and Steinsson, J., 2018. High frequency identification of monetary nonneutrality: The information effect. Quarterly Journal of Economics, forthcoming.

Nimark, K., 2008. Monetary policy with signal extraction from the bond market. Journal of Monetary Economics, 55(8), p.1389-1400.

Piazzesi, M., and Schneider, M., 2007. Equilibrium yield curves. In: Acemoglu, D., Rogoff, K., and Woodford, M. eds. NBER Macroeconomics Annual 2006. Cambridge: The MIT Press, p.389-472. 
Rolley, V.V., and Sellon, G.H.Jr., 1995. Monetary policy actions and long-term interest rates. Federal Reserve Bank of Kansas City Economic Review, 80(4), p.77-89.

Romer, C.D., and Romer, D.H., 2000. Federal Reserve information and the behavior of interest rates. American Economic Review, 90(3), p.429-457.

Romer, C.D., and Romer, D.H., 2004. A new measure of monetary shocks: Derivation and implications. American Economic Review, 94(4), p.1055-1084.

Rusnak, M., Havranek, T., and Horvath, R., 2013. How to solve the price puzzle? A metaanalysis. Journal of Money, Credit and Banking, 45(1), p.37-70.

Sarno, L., Thornton, D.L., and Valente, G., 2007. The empirical failure of the expectations hypothesis of the term structure of bond yields. Journal of Financial and Quantitative Analysis, 42(1), p.81-100.

Sims, C., 2003. Implications of rational inattention. Journal of Monetary Economics, 50(3), p.665-690.

Stock, J., and Watson, M., 1999. Forecasting inflation. Journal of Monetary Economics, 44(2), p. 293-335.

Thornton, D.L., 2005. Tests of the expectations hypothesis: resolving the anomalies when the short-term rate is the Federal funds rate. Journal of Banking and Finance, 29(10), p.2541-2556.

Thornton, D.L., 2012. Evidence on the portfolio balance channel of quantitative easing. Federal Reserve Bank of St. Louis Working Paper Series, Working paper 2012-015A.

Uhlig, H., 2005. What are the effects of monetary policy on output? Results from an agnostic identification procedure. Journal of Monetary Economics, 52(2), p.381-419.

Vayanos, D., and Vila, J-L., 2009. A preferred-habitat model of the term structure of interest rates. NBER Working Paper Series, Working paper 15487. 
Figure 1: Policy rate and monetary aggregates

FFR target

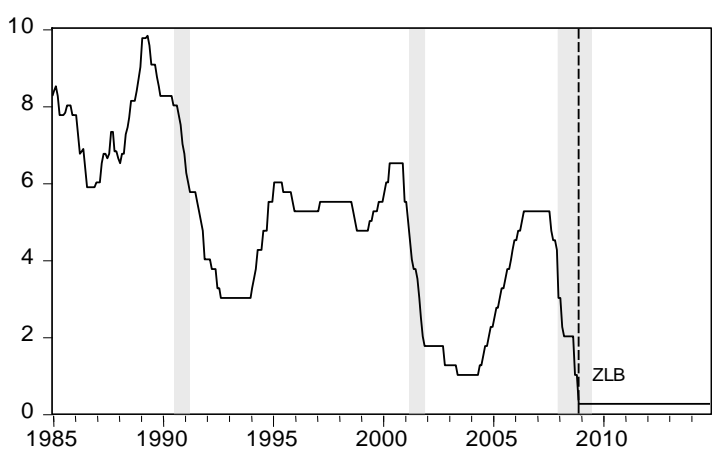

M2

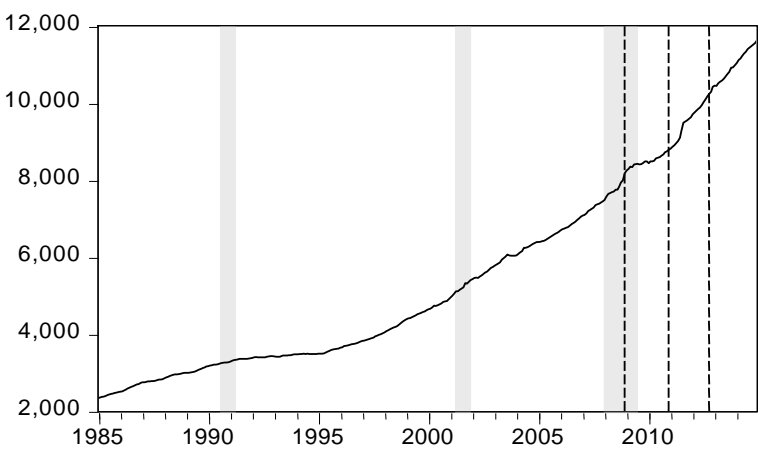

Total Reserves

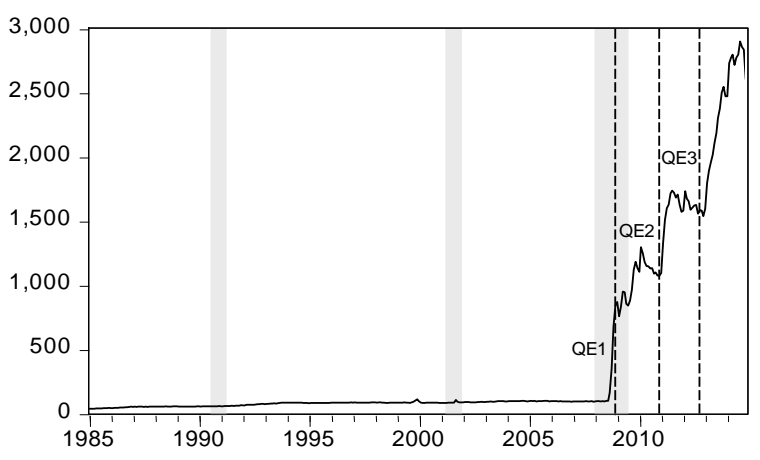

Monetary Base

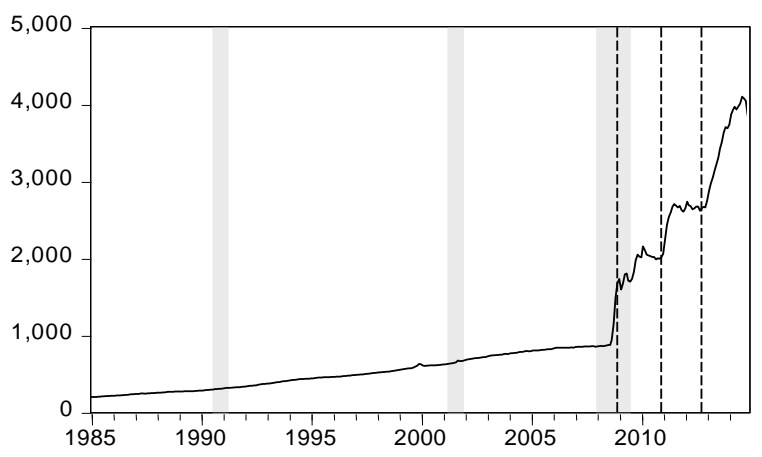

Notes: This figure plots the target Federal funds rate (FFR target), the St. Louis adjusted total reserves (in \$bn), the M2 money stock (in \$bn) and the St. Louis adjusted monetary base (in \$bn) over the period 1985:1 - 2014:2. The dashed vertical line in the upper left panel denotes the start of zero lower bound period. In the rest of the panels, the three dashed vertical lines denote the announcements of first round of quantitative easing (QE1, 2008:11), second round (QE2, 2010:11) and third round (QE3, 2012:9). Shaded areas denote US recessions as classified by NBER business cycle dates. Data is obtained from the FREDII database.

\section{Figure 2: Monetary policy indicators}

Unexpected FFR change

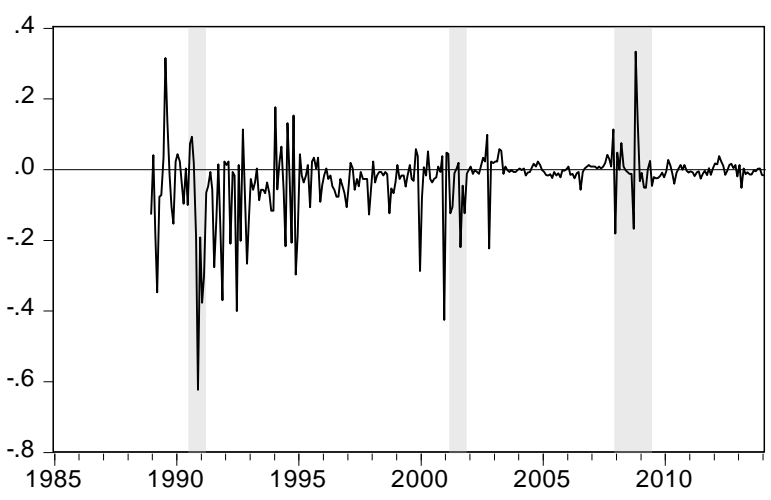

Unexpected MB change

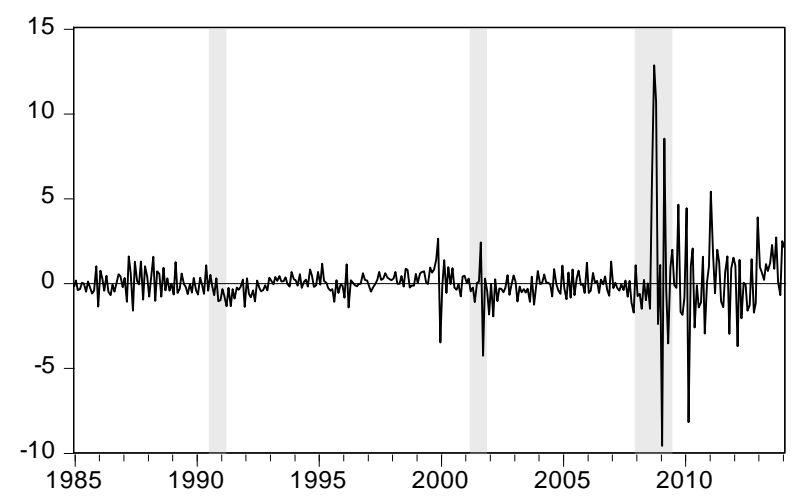

Notes: This figure plots the unexpected change in the Federal funds rate (FFR) and the unexpected change in log monetary base (MB) over the period 1985:1 - 2014:2. For further details, see Section 3.3. Shaded areas denote US recessions as classified by NBER business cycle dates. 


\section{Figure 3: Recursive estimates of unexpected MB change impact}

Panel A: 10-year bonds

Response of unexpected excess returns: 10-year bonds

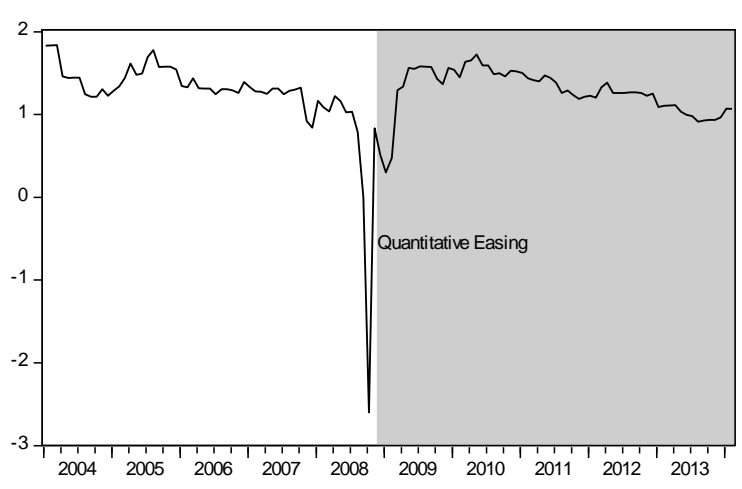

Response of revisions in inflation expectations

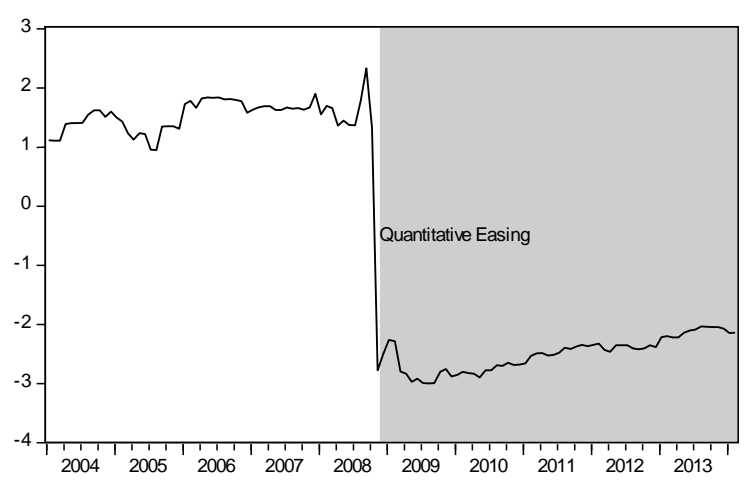

Panel B: 5-year bonds

Response of unexpected excess returns: 5 -year bonds

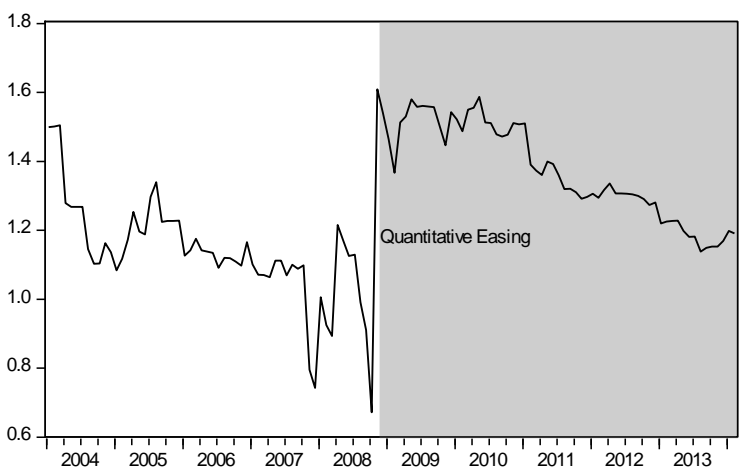

Response of revisionsin inflation expectations

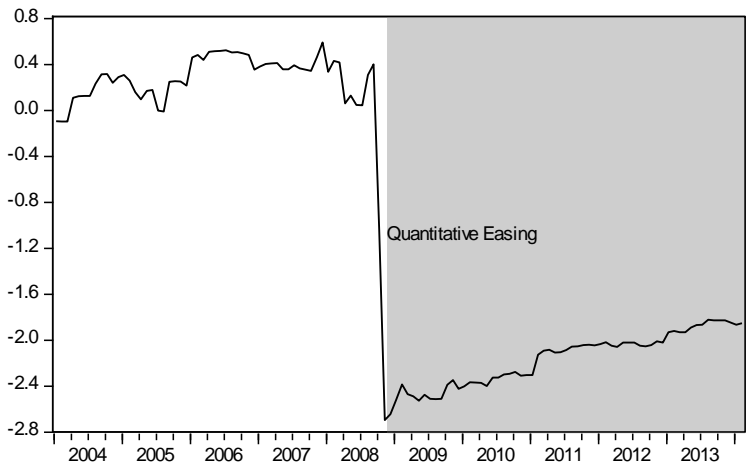

Panel C: 2-year bonds

Response of unexpected excess returns: 2-year bonds

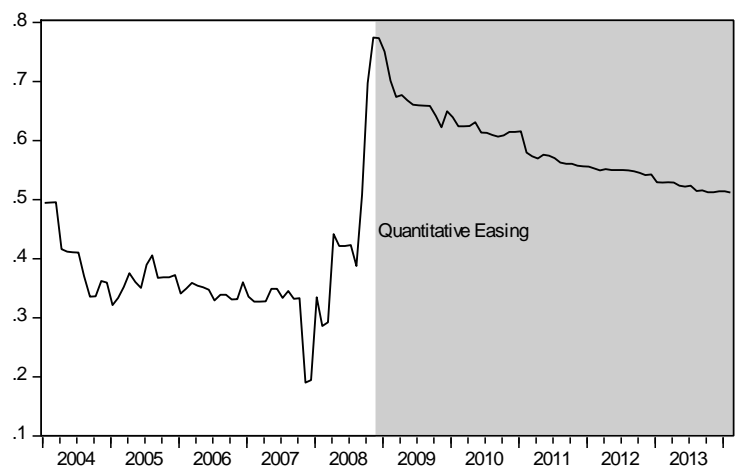

Response of revisionsin inflation expectations

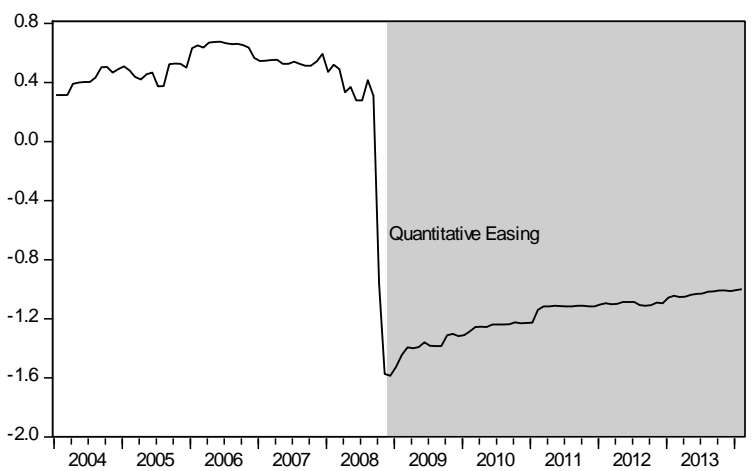

Notes: This figure plots recursive estimates of the response parameters of unexpected excess Treasury bond returns and the corresponding inflation news component to unexpected changes in log monetary base (MB). Panel A refers to 10-year bonds, Panel B to 5-year bonds and Panel C to 2-year bonds. The initial sample of the recursive estimation is 1985:1 - 1995:1 and then one month is added at each step. The shaded area denotes the period of quantitative easing, starting from the announcement of QE1 (2008:11). 
Table 1: VAR estimates

\begin{tabular}{|c|c|c|c|c|c|c|c|c|c|c|c|c|c|c|c|}
\hline \multicolumn{6}{|c|}{ 10-year bonds } & \multicolumn{5}{|c|}{ 5-year bonds } & \multicolumn{5}{|c|}{ 2-year bonds } \\
\hline \multicolumn{16}{|c|}{ 1985:1 - 2014:2 } \\
\hline & $\Delta y_{1, t}$ & $s_{n, t}$ & $r_{t}^{i}$ & $r b_{t}$ & $R^{2}$ & $\Delta y_{1, t}$ & $S_{n, t}$ & $r_{t}^{i}$ & $r b_{t}$ & $R^{2}$ & $\Delta y_{1, t}$ & $s_{n, t}$ & $r_{t}^{i}$ & $r b_{t}$ & $R^{2}$ \\
\hline$\Delta y_{1, t+1}$ & $\begin{array}{c}-0.425 * * * \\
(0.072)\end{array}$ & $\begin{array}{c}0.085^{* * * *} \\
(0.026)\end{array}$ & $\begin{array}{l}-0.010 \\
(0.007) \\
\end{array}$ & $\begin{array}{c}0.103 * * \\
(0.041) \\
\end{array}$ & 0.196 & $\begin{array}{l}-0.414 * * * \\
(0.073)\end{array}$ & $\begin{array}{l}0.148 * * * \\
(0.032)\end{array}$ & $\begin{array}{l}-0.011 \\
(0.007) \\
\end{array}$ & $\begin{array}{l}0.110 * * * \\
(0.038)\end{array}$ & 0.236 & $\begin{array}{l}-0.359 * * * \\
(0.073)\end{array}$ & $\begin{array}{l}0.271^{* * *} \\
(0.041)\end{array}$ & $\begin{array}{l}-0.017 * * * \\
(0.006)\end{array}$ & $\begin{array}{l}0.067 * \\
(0.035)\end{array}$ & 0.322 \\
\hline$s_{n, t+1}$ & $\begin{array}{c}0.431^{* * * *} \\
(0.078)\end{array}$ & $\begin{array}{c}0.885^{* * * *} \\
(0.028)\end{array}$ & $\begin{array}{l}-0.000 \\
(0.009)\end{array}$ & $\begin{array}{c}-0.129 * * * \\
(0.047)\end{array}$ & 0.814 & $\begin{array}{l}0.396^{* * * *} \\
(0.078)\end{array}$ & $\begin{array}{l}0.834 * * * \\
(0.035)\end{array}$ & $\begin{array}{l}0.003 \\
(0.008) \\
\end{array}$ & $\begin{array}{l}-0.107 * * \\
(0.045)\end{array}$ & 0.719 & $\begin{array}{l}0.328 * * * \\
(0.080)\end{array}$ & $\begin{array}{l}0.754^{* * * *} \\
(0.046)\end{array}$ & $\begin{array}{l}0.008 \\
(0.007)\end{array}$ & $\begin{array}{l}-0.031 \\
(0.042)\end{array}$ & 0.557 \\
\hline$r_{t+1}^{i}$ & $\begin{array}{c}0.139 \\
(0.284) \\
\end{array}$ & $\begin{array}{c}-0.366^{* *} \\
(0.150) \\
\end{array}$ & $\begin{array}{c}0.515^{* * * *} \\
(0.077)\end{array}$ & $\begin{array}{l}-0.106 \\
(0.217) \\
\end{array}$ & 0.324 & $\begin{array}{l}0.124 \\
(0.282)\end{array}$ & $\begin{array}{l}-0.215 \\
(0.143) \\
\end{array}$ & $\begin{array}{l}0.545^{* * *} * \\
(0.070)\end{array}$ & $\begin{array}{l}0.042 \\
(0.220)\end{array}$ & 0.313 & $\begin{array}{l}0.137 \\
(0.283)\end{array}$ & $\begin{array}{l}-0.018 \\
(0.169)\end{array}$ & $\begin{array}{l}0.557 * * * \\
(0.068)\end{array}$ & $\begin{array}{l}0.132 \\
(0.219) \\
\end{array}$ & 0.400 \\
\hline$r b_{t+1}$ & $\begin{array}{c}-0.382 * * * \\
(0.070)\end{array}$ & $\begin{array}{c}0.096^{* * *} * \\
(0.026)\end{array}$ & $\begin{array}{l}-0.010 \\
(0.007) \\
\end{array}$ & $\begin{array}{c}0.974 * * * \\
(0.039)\end{array}$ & 0.711 & $\begin{array}{l}-0.369 * * * \\
(0.071)\end{array}$ & $\begin{array}{l}0.157 * * * \\
(0.032)\end{array}$ & $\begin{array}{l}-0.012 * * \\
(0.006)\end{array}$ & $\begin{array}{l}0.978 * * * \\
(0.037)\end{array}$ & 0.726 & $\begin{array}{l}-0.315^{* * * *} \\
(0.071)\end{array}$ & $\begin{array}{l}0.272 * * * \\
(0.041)\end{array}$ & $\begin{array}{l}-0.018 * * * \\
(0.006)\end{array}$ & $\begin{array}{l}0.931 * * * \\
(0.033)\end{array}$ & 0.756 \\
\hline \multicolumn{16}{|c|}{ 1985:1 - 2007:7 } \\
\hline$\Delta y_{1, t+1}$ & $\begin{array}{l}-0.443 * * * \\
(0.075)\end{array}$ & $\begin{array}{l}0.087 * * * \\
(0.032)\end{array}$ & $\begin{array}{l}-0.015 \\
(0.012)\end{array}$ & $\begin{array}{l}0.098 * * \\
(0.048)\end{array}$ & 0.215 & $\begin{array}{l}-0.433 * * * \\
(0.073)\end{array}$ & $\begin{array}{l}0.148 * * * \\
(0.032)\end{array}$ & $\begin{array}{l}-0.013 \\
(0.011)\end{array}$ & $\begin{array}{l}0.112 * * \\
(0.045)\end{array}$ & 0.249 & $\begin{array}{l}-0.374 * * * \\
(0.076)\end{array}$ & $\begin{array}{l}0.279 * * * \\
(0.046)\end{array}$ & $\begin{array}{l}-0.015 \\
(0.010)\end{array}$ & $\begin{array}{l}0.075^{*} \\
(0.038)\end{array}$ & 0.334 \\
\hline$s_{n, t+1}$ & $\begin{array}{l}0.431 * * * \\
(0.081)\end{array}$ & $\begin{array}{l}0.886 * * * \\
(0.036) \\
\end{array}$ & $\begin{array}{l}0.007 \\
(0.015) \\
\end{array}$ & $\begin{array}{l}-0.121^{* *} \\
(0.055) \\
\end{array}$ & 0.802 & $\begin{array}{l}0.394 * * * \\
(0.082)\end{array}$ & $\begin{array}{l}0.830 * * * \\
(0.043) \\
\end{array}$ & $\begin{array}{l}0.004 \\
(0.014) \\
\end{array}$ & $\begin{array}{l}-0.110 * * \\
(0.054) \\
\end{array}$ & 0.708 & $\begin{array}{l}0.323 * * * \\
(0.084) \\
\end{array}$ & $\begin{array}{l}0.736^{* * * *} \\
(0.053) \\
\end{array}$ & $\begin{array}{l}0.003 \\
(0.012) \\
\end{array}$ & $\begin{array}{l}-0.038 \\
(0.048) \\
\end{array}$ & 0.523 \\
\hline$r_{t+1}^{i}$ & $\begin{array}{l}0.242 \\
(0.265)\end{array}$ & $\begin{array}{l}-0.488 * * * \\
(0.140)\end{array}$ & $\begin{array}{l}0.399 * * * \\
(0.083)\end{array}$ & $\begin{array}{l}-0.358^{*} \\
(0.195)\end{array}$ & 0.266 & $\begin{array}{l}0.204 \\
(0.265)\end{array}$ & $\begin{array}{l}-0.416^{* * * *} \\
(0.155)\end{array}$ & $\begin{array}{l}0.434 * * * \\
(0.081)\end{array}$ & $\begin{array}{l}-0.215 \\
(0.193)\end{array}$ & 0.250 & $\begin{array}{l}0.157 \\
(0.266)\end{array}$ & $\begin{array}{l}-0.281 \\
(0.183)\end{array}$ & $\begin{array}{l}0.465 * * * \\
(0.080)\end{array}$ & $\begin{array}{l}-0.032 \\
(0.194)\end{array}$ & 0.236 \\
\hline$r b_{t+1}$ & $\begin{array}{l}-0.401 * * * \\
(0.074)\end{array}$ & $\begin{array}{l}0.098 * * * \\
(0.032)\end{array}$ & $\begin{array}{l}-0.015 \\
(0.012)\end{array}$ & $\begin{array}{l}0.971 * * * \\
(0.046)\end{array}$ & 0.687 & $\begin{array}{l}-0.390 * * * \\
(0.075)\end{array}$ & $\begin{array}{l}0.156 * * * \\
(0.038)\end{array}$ & $\begin{array}{l}-0.015 \\
(0.011)\end{array}$ & $\begin{array}{l}0.982 * * * \\
(0.043)\end{array}$ & 0.700 & $\begin{array}{l}-0.332 * * * \\
(0.075)\end{array}$ & $\begin{array}{l}0.278 * * * \\
(0.046)\end{array}$ & $\begin{array}{l}-0.017^{*} \\
(0.010) \\
\end{array}$ & $\begin{array}{l}0.940 * * * \\
(0.037)\end{array}$ & 0.733 \\
\hline
\end{tabular}

Notes: This table reports the estimated parameters of the benchmark VAR(1) model shown in Equation (3) for 10-, 5- and 2-year bonds. The state vector contains the first difference in 1-month Treasury bill rate $\left(\Delta y_{1}\right)$, the yield spread between 10-, 5- and 2-year Treasury bonds and the 1-month Treasury bill $\left(s_{n}\right)$, the real interest rate $\left(r^{i}\right)$ and the relative bill rate $(r b)$. All variables are expressed in percentages per annum on continuously compounded basis. The upper panel of the table provides the full sample (1985:1 - 2014:2) estimates while the pre-crisis period (1985:1 - 2007:7) estimates are shown in the lower panel. Heteroskedasticity-consistent standard errors are shown in parentheses. $* * *, * * *$ denote $1 \%, 5 \%$ and $10 \%$ level of significance, respectively. 
Table 2: Variance decomposition for excess bond returns

\begin{tabular}{|c|c|c|c|c|c|c|}
\hline & \multicolumn{2}{|c|}{ 10-year bonds } & \multicolumn{2}{|c|}{ 5-year bonds } & \multicolumn{2}{|c|}{ 2-year bonds } \\
\hline & 1985:1-2014:2 & 1985:1-2007:7 & 1985:1-2014:2 & 1985:1-2007:7 & $\begin{array}{l}\text { 1985:1- } \\
\text { 2013:12 }\end{array}$ & 1985:1-2007:7 \\
\hline $\operatorname{Var}(80)$ & $\begin{array}{l}0.833^{* * * *} \\
(0.264)\end{array}$ & $\begin{array}{l}0.799 * * * \\
(0.243)\end{array}$ & $\begin{array}{l}1.108 * * \\
(0.430)\end{array}$ & $\begin{array}{c}1.116^{* *} \\
(0.447) \\
\end{array}$ & $\begin{array}{l}1.607 * * \\
(0.763) \\
\end{array}$ & $\begin{array}{c}1.675^{* *} \\
(0.700) \\
\end{array}$ \\
\hline $2 \operatorname{Cov}\left(\varnothing_{\pi}, \varnothing_{r^{\prime}}\right)$ & $\begin{array}{l}-0.087 \\
(0.083) \\
\end{array}$ & $\begin{array}{l}-0.085 \\
(0.087) \\
\end{array}$ & $\begin{array}{c}-0.189 \\
(0.189) \\
\end{array}$ & $\begin{array}{l}-0.225 \\
(0.191) \\
\end{array}$ & $\begin{array}{c}-0.674 \\
(0.698) \\
\end{array}$ & $\begin{array}{c}-0.673 \\
(0.595) \\
\end{array}$ \\
\hline $2 \operatorname{Cov}\left(\theta_{\pi}, \varnothing_{x}\right)$ & $\begin{array}{c}0.046 \\
(0.285) \\
\end{array}$ & $\begin{array}{c}0.148 \\
(0.200) \\
\end{array}$ & $\begin{array}{c}-0.098 \\
(0.352) \\
\end{array}$ & $\begin{array}{c}0.015 \\
(0.331) \\
\end{array}$ & $\begin{array}{c}-0.553 \\
(0.448) \\
\end{array}$ & $\begin{array}{c}-0.314 \\
(0.421) \\
\end{array}$ \\
\hline $\operatorname{Var}\left(\underset{r^{\prime}}{\ell_{1}}\right)$ & $\begin{array}{l}0.018 * \\
(0.010)\end{array}$ & $\begin{array}{c}0.017 \\
(0.012)\end{array}$ & $\begin{array}{c}0.038 \\
(0.023)\end{array}$ & $\begin{array}{c}0.035 \\
(0.024)\end{array}$ & $\begin{array}{l}0.266^{*} \\
(0.147)\end{array}$ & $\begin{array}{c}0.143 \\
(0.111)\end{array}$ \\
\hline $2 \operatorname{Cov}\left(\ell_{r}, \ell_{x}\right)$ & $\begin{array}{c}-0.068 \\
(0.056) \\
\end{array}$ & $\begin{array}{l}-0.102^{*} \\
(0.058) \\
\end{array}$ & $\begin{array}{c}0.025 \\
(0.067) \\
\end{array}$ & $\begin{array}{c}-0.052 \\
(0.069) \\
\end{array}$ & $\begin{array}{c}0.252 \\
(0.171) \\
\end{array}$ & $\begin{array}{c}0.081 \\
(0.128) \\
\end{array}$ \\
\hline $\operatorname{Var}\left(X_{x}\right)$ & $\begin{array}{c}0.258 \\
(0.168) \\
\end{array}$ & $\begin{array}{c}0.223 \\
(0.177) \\
\end{array}$ & $\begin{array}{c}0.116 \\
(0.101) \\
\end{array}$ & $\begin{array}{c}0.112 \\
(0.109) \\
\end{array}$ & $\begin{array}{c}0.102 \\
(0.074) \\
\end{array}$ & $\begin{array}{c}0.088 \\
(0.070) \\
\end{array}$ \\
\hline$R^{2}\left(\theta_{\pi}\right)$ & $\begin{array}{l}0.793 * * * \\
(0.154) \\
\end{array}$ & $\begin{array}{l}0.863 * * * \\
(0.140)\end{array}$ & $\begin{array}{c}0.839 * * * \\
(0.113) \\
\end{array}$ & $\begin{array}{c}0.915 * * * \\
(0.083)\end{array}$ & $\begin{array}{c}0.614 * * * \\
(0.163)\end{array}$ & $\begin{array}{c}0.834 * * * \\
(0.102) \\
\end{array}$ \\
\hline$R^{2}\left(\underset{r^{\prime}}{X_{0}}\right)$ & $\begin{array}{c}0.199 \\
(0.145)\end{array}$ & $\begin{array}{c}0.334 * * \\
(0.152)\end{array}$ & $\begin{array}{c}0.050 \\
(0.133) \\
\end{array}$ & $\begin{array}{c}0.314 \\
(0.202) \\
\end{array}$ & $\begin{array}{c}0.011 \\
(0.087) \\
\end{array}$ & $\begin{array}{c}0.164 \\
(0.252) \\
\end{array}$ \\
\hline$R^{2}\left(\ell_{x}\right)$ & $\begin{array}{c}0.236 \\
(0.202) \\
\end{array}$ & $\begin{array}{c}0.271 \\
(0.203) \\
\end{array}$ & $\begin{array}{c}0.054 \\
(0.221) \\
\end{array}$ & $\begin{array}{c}0.078 \\
(0.268) \\
\end{array}$ & $\begin{array}{c}0.023 \\
(0.149) \\
\end{array}$ & $\begin{array}{c}0.009 \\
(0.103) \\
\end{array}$ \\
\hline
\end{tabular}

Notes: This table reports the variance decomposition of unexpected excess returns of 10-, 5-, and 2-year Treasury bonds into the variances of inflation news $\left(\ell_{T}\right)$, real interest rate news $\left(\ell_{r^{\prime}}\right)$, risk premium news $\left(\ell_{x}\right)$ and the covariances between these three components. News components are extracted from a VAR(1) model where the state vector contains the first difference in 1-month Treasury bill rate, the yield spread between 10-, 5- and 2-year Treasury bonds and the 1-month Treasury bill, the real interest rate and the relative bill rate. The first and second column for each bond maturity report the full sample $\left(1985: 1\right.$ - 2014:2) and pre-crisis period (1985:1 - 2007:7) results, respectively. $\mathrm{R}^{2}$ values are obtained from regressions of unexpected excess returns on each news component. The standard errors reported in parentheses are computed using the delta method. ***,**, $*$ denote $1 \%, 5 \%$ and $10 \%$ level of significance, respectively.. 
Table 3: Impact of monetary policy on excess bond returns - Unexpected FFR change

\begin{tabular}{|c|c|c|c|c|c|c|}
\hline \multicolumn{3}{|c|}{ 10-year bonds } & \multicolumn{2}{c|}{ 5-year bonds } & \multicolumn{2}{c|}{ 2-year bonds } \\
\hline$\Delta F F R^{U}$ & $\mathbf{1 9 8 9 : 2 - 2 0 1 4 : 2}$ & $\mathbf{1 9 8 9 : 2 - 2 0 0 7 : 7}$ & $\mathbf{1 9 8 9 : 2 - 2 0 1 4 : 2}$ & $\mathbf{1 9 8 9 : 2 - 2 0 0 7 : 7}$ & $\mathbf{1 9 8 9 : 2}-\mathbf{2 0 1 4 : 2}$ & $\mathbf{1 9 8 9 : 2 - 2 0 0 7 : 7}$ \\
\hline$\ell_{n}^{M P}$ & $-24.32^{* * *}$ & $-54.00^{* * *}$ & $-25.57 * * *$ & $-34.73^{* * *}$ & $-17.34 * * *$ & $-19.22^{* * *}$ \\
& $(1.963)$ & $(3.511)$ & $(1.341)$ & $(1.799)$ & $(0.712)$ & $(0.732)$ \\
\hline$\ell_{r^{i}}^{M P}$ & $-1.78^{* *}$ & -2.37 & -0.56 & -0.73 & 2.04 & 1.90 \\
& $(0.863)$ & $(1.444)$ & $(1.616)$ & $(1.943)$ & $(3.305)$ & $(3.461)$ \\
\hline$\ell_{\pi}^{M P}$ & $16.70^{* * *}$ & $44.21^{* * *}$ & $24.04 * * *$ & $33.43^{* * *}$ & $16.31 * * *$ & $18.45^{* * *}$ \\
\hline$\ell_{x}^{M P}$ & $(3.687)$ & $(6.009)$ & $(5.145)$ & $(5.804)$ & $(4.713)$ & $(4.726)$ \\
\hline & $9.39 * *$ & $12.16^{*}$ & 2.10 & 2.03 & -1.02 & -1.13 \\
\hline
\end{tabular}

Notes: This table reports the impact of an unexpected change in the Federal funds rate (FFR) on the unexpected excess returns of 10-, 5-, and 2-year Treasury bonds $\left(\ell_{n}\right)$, inflation news $\left(\ell_{\pi}\right)$, real interest rate news $\left(\ell_{r^{\prime}}\right)$ and risk premium news $\left(\ell_{x}\right)$. News components are extracted from a VAR(1) model estimated over the period 1985:1 - 2014:2. The state vector contains the first difference in 1-month Treasury bill rate, the yield spread between 10-, 5- and 2-year Treasury bonds and the 1-month Treasury bill, the real interest rate and the relative bill rate. The first and second column for each bond maturity report the full sample (1989:2 - 2014:2) and pre-crisis period (1989:2 - 2007:7) results, respectively. The standard errors reported in parentheses are computed using the delta method. ***, **, * denote $1 \%, 5 \%$ and $10 \%$ level of significance, respectively.

Table 4: Impact of monetary policy on excess bond returns - Unexpected MB change

\begin{tabular}{|c|c|c|c|c|c|c|}
\hline \multicolumn{3}{|c|}{ 10-year bonds } & \multicolumn{2}{|c|}{ 5-year bonds } & \multicolumn{2}{|c|}{ 2-year bonds } \\
\hline$\Delta M B^{U}$ & 1985:1 - 2014:2 & 1985:1 - 2007:7 & 1985:1 - 2014:2 & 1985:1 - 2007:7 & 1985:1 - 2014:2 & 1985:1 - 2007:7 \\
\hline$\underset{n}{M P}$ & $\begin{array}{l}1.05 * * * \\
(0.102)\end{array}$ & $\begin{array}{l}1.23 * * \\
(0.537)\end{array}$ & $\begin{array}{l}1.19 * * * \\
(0.048)\end{array}$ & $\begin{array}{l}1.07 * * * \\
(0.328)\end{array}$ & $\begin{array}{c}0.51 * * * \\
(0.018)\end{array}$ & $\begin{array}{l}0.33^{* *} \\
(0.147)\end{array}$ \\
\hline $\log _{r^{i}}^{M P}$ & $\begin{array}{l}0.30 * * \\
(0.123)\end{array}$ & $\begin{array}{c}0.02 \\
(0.251)\end{array}$ & $\begin{array}{l}0.34 * * \\
(0.138)\end{array}$ & $\begin{array}{c}-0.29 \\
(0.209)\end{array}$ & $\begin{array}{c}0.31 * \\
(0.159)\end{array}$ & $\begin{array}{c}-0.52 * * * \\
(0.184)\end{array}$ \\
\hline$\ell_{\frac{O}{\pi}}^{M P}$ & $\begin{array}{c}-2.16 * * * \\
(0.596)\end{array}$ & $\begin{array}{c}1.65 \\
(1.233)\end{array}$ & $\begin{array}{c}-1.86 * * * \\
(0.407)\end{array}$ & $\begin{array}{c}0.38 \\
(0.719)\end{array}$ & $\begin{array}{c}-1.01 * * * \\
(0.234)\end{array}$ & $\begin{array}{c}0.53 \\
(0.322) \\
\end{array}$ \\
\hline$\ell_{x}^{M P}$ & $\begin{array}{c}0.81 \\
(0.533)\end{array}$ & $\begin{array}{c}-2.90 * * * \\
(1.102)\end{array}$ & $\begin{array}{c}0.34 \\
(0.294)\end{array}$ & $\begin{array}{l}-1.16^{* *} \\
(0.511)\end{array}$ & $\begin{array}{c}0.19 * \\
(0.103)\end{array}$ & $\begin{array}{l}-0.34 * * \\
(0.151)\end{array}$ \\
\hline
\end{tabular}

Notes: This table reports the impact of an unexpected change in log monetary base (MB) on the unexpected excess returns of 10-, 5-, and 2-year Treasury bonds $\left(\varnothing_{n}\right)$, inflation news $\left(\varnothing_{\pi}\right)$, real interest rate news $\left(\ell_{r^{i}}\right)$ and risk premium news $\left(\ell_{x}\right)$.News components are extracted from a VAR(1) model estimated over the period 1985:1 - 2014:2. The state vector contains the first difference in 1-month Treasury bill rate, the yield spread between 10-, 5- and 2-year Treasury bonds and the 1-month Treasury bill, the real interest rate and the relative bill rate. The first and second column for each bond maturity report the full sample (1985:1 - 2014:2) and pre-crisis period (1985:1 - 2007:7) results, respectively. The standard errors reported in parentheses are computed using the delta method. ***, **, * denote 1\%, 5\% and 10\% level of significance, respectively. 